\title{
OPTIMALISASI TELEPON PINTAR UNTUK SISTEM KEAMANAN SEPEDA MOTOR BERBASIS FREKUENSI RADIO
}

\author{
Muhammad Yanuardi \\ Fakultas Teknik, Program Studi Teknik Elektro \\ Universitas Bangka Belitung \\ Email: mhmd.yanuardi@gmail.com \\ Muhammad Jumnahdi \\ Fakultas Teknik, Program Studi Teknik Elektro \\ Universitas Bangka Belitung \\ Email: muhd.jumnahdi@gmail.com \\ Rika Favoria Gusa \\ Fakultas Teknik, Program Studi Teknik Elektro \\ Universitas Bangka Belitung \\ Email: rikafavoriagusa@gmail.com
}

\begin{abstract}
ABSTRAK
Pertambahan jumlah penduduk berbanding lurus dengan jumlah kendaraan sepeda motor, namun tidak diikuti dengan kedisiplinan pengguna sepeda motor itu sendiri sehingga angka kecelakaan dan tindak pencurian terhadap sepeda motor terus bertambah. Penelitian ini menggunakan modul nRF24L01 dengan tujuan agar sepeda motor dapat diintegrasikan dengan helm secara nirkabel untuk memberi peringatan dini kepada pengendara dan menggunakan modul SIM800L sebagai media komunikasi pesan singkat dengan smartphone untuk melacak posisi sepeda motor. Peringatan dini berupa kunci kontak diaktifkan dengan cara memasang tali pemegang helm, bunyi yang menggambarkan jarak objek di belakang sepeda motor dan suara yang memberitahukan kecepatan sepeda motor. Kunci kontak diaktifkan dengan jarak maksimal 80 meter, waktu tanggapan tercepat 0,9 detik dan waktu tanggapan terlama 11 detik. Waktu tanggapan bunyi tercepat 3,6 detik dan terlama 4,2 detik. Waktu tanggapan suara tercepat 2,50 detik dan terlama 3,31 detik. Sedangkan untuk melacak posisi sepeda motor dengan pesan singkat dilakukan pada ruang tertutup dan terbuka dengan waktu respon pesan singkat tercepat pada ruang tertutup 11,08 detik dan ruang terbuka 11,36 detik. Akurasi pembacaan posisi sepeda motor terbaik pada ruang tertutup 1,55 meter dan 1,09 meter untuk ruang terbuka.
\end{abstract}

Kata kunci: nRF24L01; nirkabel; peringatan dini.

\begin{abstract}
The increase of population is directly proportional to the number of motorcycles, but was not followed by the discipline of motorcycle users themselves so that the number of accidents and acts of theft against motorcycles continue to grow. This research using nRF24L01 module with the goal of keeping the motorcycle can be integrated with wireless helmet to give early warning to motorists and using the SIM800L module as short message communication media with the Smartphones to track the position of the motorcycle. Early warning in the form of key contact is activated by installing the helmet holder strap, the sound which describes the object distance behind motor cycle and the voice that tells the speed of the motorcycle. Key contact is activated with maximum distance of 80 metres, the fastest response time 0.9 seconds and the longest response time of 11 seconds. The fastest response time 3.6 seconds and the sound of the longest 4.2 seconds. Voice response time 2.50 seconds for the fastest and the longest 3.31 seconds. Whereas in order to track the position of motorcycle with short message made on indoor and outdoor space with the fastest response time of short message in the indoor space 11,08 seconds and outdoor space 11,36 seconds. The best accuracy of the reading of motorcycle position was 1.55 meters in indoor space and 1.09 meters for outdoor space.
\end{abstract}

Keywords: nRF24L01; wireless; early warning. 


\section{PENDAHULUAN}

Jumlah kendaraan sepeda motor di Indonesia dari waktu ke waktu semakin bertambah tercatat pada tahun 2015 jumlah sepeda motor 98.881 .267 unit dan meningkat 5,96\% pada tahun 2016 menjadi 105.150.082 unit. Namun bertambahnya jumlah sepeda motor tidak dengan kedisiplinan dari pengendaranya itu sendiri sehingga mudah terlibat kecelakaan yang dapat menyebabkan luka serius. Angka kecelakaan tertinggi dialami oleh pengendara sepeda motor dibandingkan kendaraan jenis lain dengan jumlah 35.491 kejadian dan begitu juga kecelakaan yang disebabkan karena melanggar aturan batas kecepatan maksimum dan minimum dengan angka tertinggi ditempati oleh sepeda motor dengan jumlah 2.016 sepeda motor [1].

Berdasarkan data yang dimiliki Satuan Lalu Lintas Kepolisian Resor Kuningan menyebutkan, lebih dari separuh korban meninggal dunia dalam kecelakaan lalu lintas disebabkan karena tindak pelanggaran lalu lintas. Dari 20.860 orang melakukan pelanggaran pada tahun 2017, 152 orang yang meninggal dunia akibat kecelakaan lalu lintas pada tahun 2017. Hal ini menunjukkan bahwa kesadaran dan disiplin pengendara sepeda motor akan pentingnya fungsi helm masih relatif rendah, ditambah lagi bahan dan struktur helm yang ada sekarang ini hanya sebatas meredam benturan, tidak untuk mencegah pengendara terhindar dari cedera serius yang berujung pada kematian [2]. Selain itu kasus pencurian sepeda motor tercatat mulai dari tahun 2011 sampai 2014 masing-masing 39.217 kasus, 41.816 kasus dan 42.508 kasus [3]. Modus operandi pencurian dengan menggunakan kunci $\mathrm{T}$ dengan nilai angka perbandingan adalah 4 dari 10 kasus pencurian kendaraan bermotor [4].

Berdasarkan permasalahan-permasalahan yang telah diuraikan, penelitian ini bertujuan untuk memaksimalkan fungsi helm tersebut yang mampu memberi peringatan kepada pengendara sepeda motor mulai dari menggunakan helm dengan benar, mengingatkan secara verbal kecepatan sepeda motor yang sedang berjalan, memberi peringatan bila ada objek di belakang pengendara dalam jarak tertentu dan kemampuan lain yang tidak kalah penting adalah posisi sepeda motor dalam peta dunia dapat dilacak melalaui smartphone.

\section{METODOLOGI PENELITIAN}

Penelitian ini meliputi beberapa tahapan diantaranya adalah perancangan model sistem, pembuatan model sistem, pemogramanan, pengujian sistem yang terbagi menjadi 4 bagian yaitu waktu tanggapan antara limit switch dan modul relay, waktu tanggapan antara sensor ultrasonik dan buzzer [5], waktu tanggapan antara sensor infra merah dan speaker, serta akurasi dan waktu tanggapan perangkat GPS. Tahapan terakhir dari penelitian adalah aplikasi sistem pada sepeda motor.

\subsection{Perancangan Model Sistem}

Secara umum rancangan model sistem terbagi dua bagian yaitu sistem yang ada pada helm yang selanjutnya disebut perangkat helm dan sistem yang diletakkan pada sepeda motor yang selanjutnya disebut perangkat sepeda motor. Sedangkan perangkat pelacak GPS yang bekerja secara terpisah disematkan dalam perangkat sepeda motor. Ilustrasi rancangan model sistem seperti ditunjukkan oleh Gambar 1.

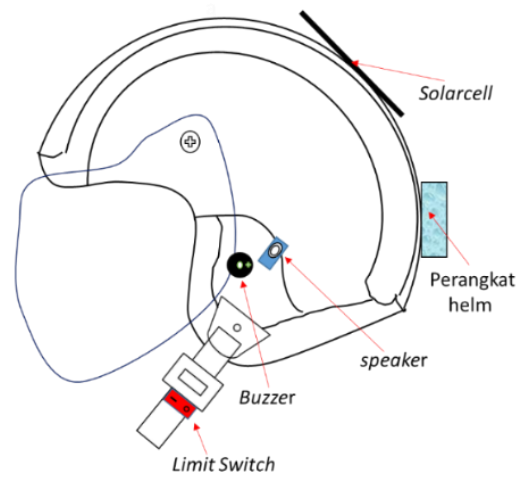

(a)

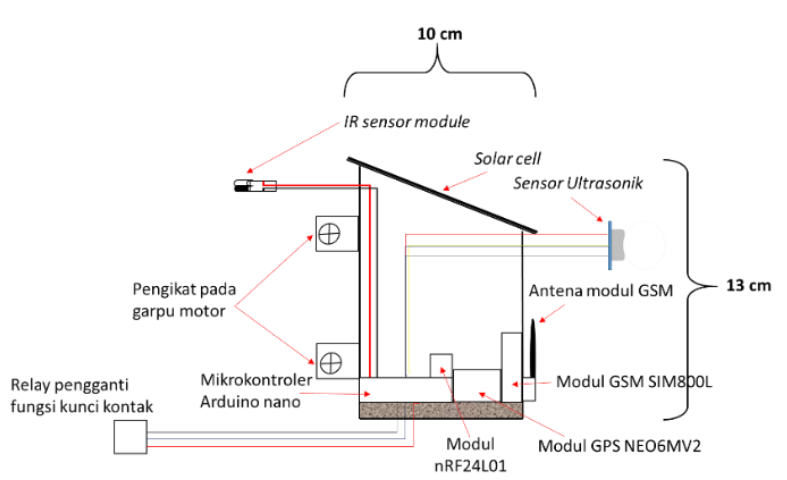

(b)

Gambar 1. Ilustrasi Rancangan (A) Perangkat Helm, (B) Perangkat Sepeda Motor 


\subsection{Pembuatan Model Sistem}

Rangkaian elektrik (skematik) model sistem terdiri dari tiga yaitu skematik perangkat sepeda motor, perangkat helm dan perangkat pelacak GPS. Komunikasi data antara perangkat sepeda motor dan perangkat helm dihubungkan melalui modul nRF24L01 dengan Arduino nano bertindak sebagai mikrokontroler[6]. Dalam perangkat sepeda motor terdapat relay sebagai output serta sensor infra merah dan sensor ultrasonik sebagai input sedangkan perangkat helm memiliki buzzer dan speaker sebagai output serta limit switch sebagai input seperti ditunjukkan oleh Gambar 2.

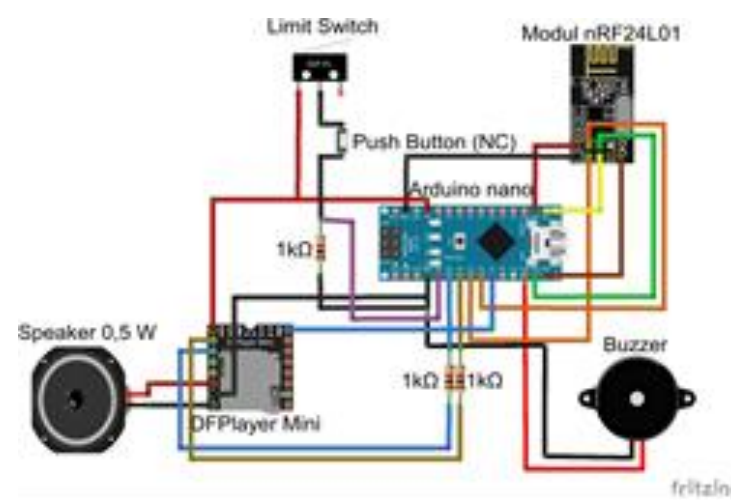

(a)

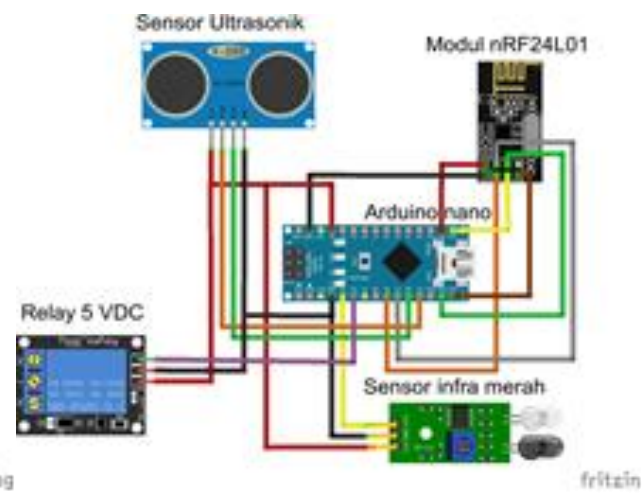

(b)

\section{Gambar 2. Skematik Rangkaian Sistem (A) Perangkat Helm, (B) Perangkat Sepeda Motor}

Perangkat pelacak GPS disusun oleh komponen besar seperti arduino nano, modul sim8001 dan modul GPS. Modul GPS bertugas sebagai input untuk memberikan nilai dari latitude dan longitude dari posisi dirinya sendiri terhadap peta dunia [7]. Arduino nano berfungsi sebagai pengelola input dan meberikan kepada perintah modul sim800L untuk menjawab pesan singkat masuk yang sesuai dengan kode program perangkat pelacak GPS.

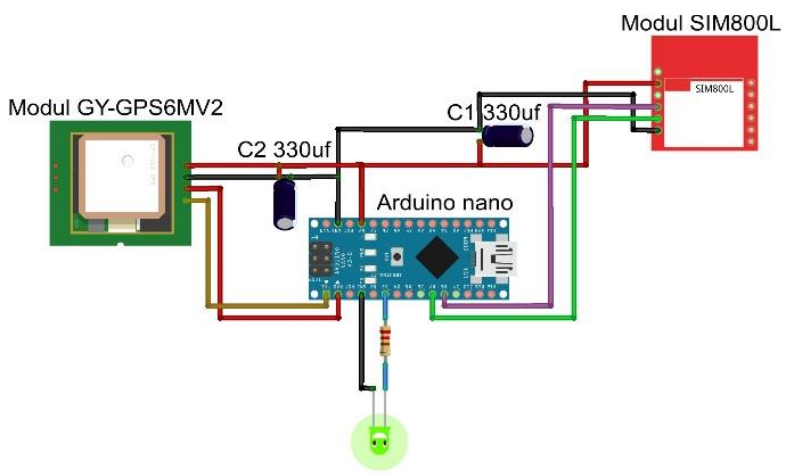

Gambar 3. Skematik Rangkaian Perangkat Pelacak GPS

\subsection{Pemograman}

Dengan menekan saklar pada perangkat sepeda motor diposisi "1" akan mengaktifkan mikrokontroler Arduino nano, relay, perangkat pelacak GPS , sensor ultrasonik, sensor inframerah dan modul nRF24L01. Perangkat pelacak GPS dengan sendirinya akan mengirim pesan singkat dengan karakter "Posisi sepeda motor ONLINE" ke nomor yang yang telah disimpan dalam kode program pelacak GPS [8]. Jika modul modul sim800L menerima pesan singkat dengan karakter "Lacak" maka akan dibalas dengan mengirimkan link google maps dimana posisi perangkat berada dan jika modul modul sim800L [9] menerima pesan singkat dengan karakter "Reset" maka kembali akan dibalas dua pesan singkat dengan karakter "Pelacak GPS telah direset" dan"Posisi sepeda motor ONLINE"[5]. 


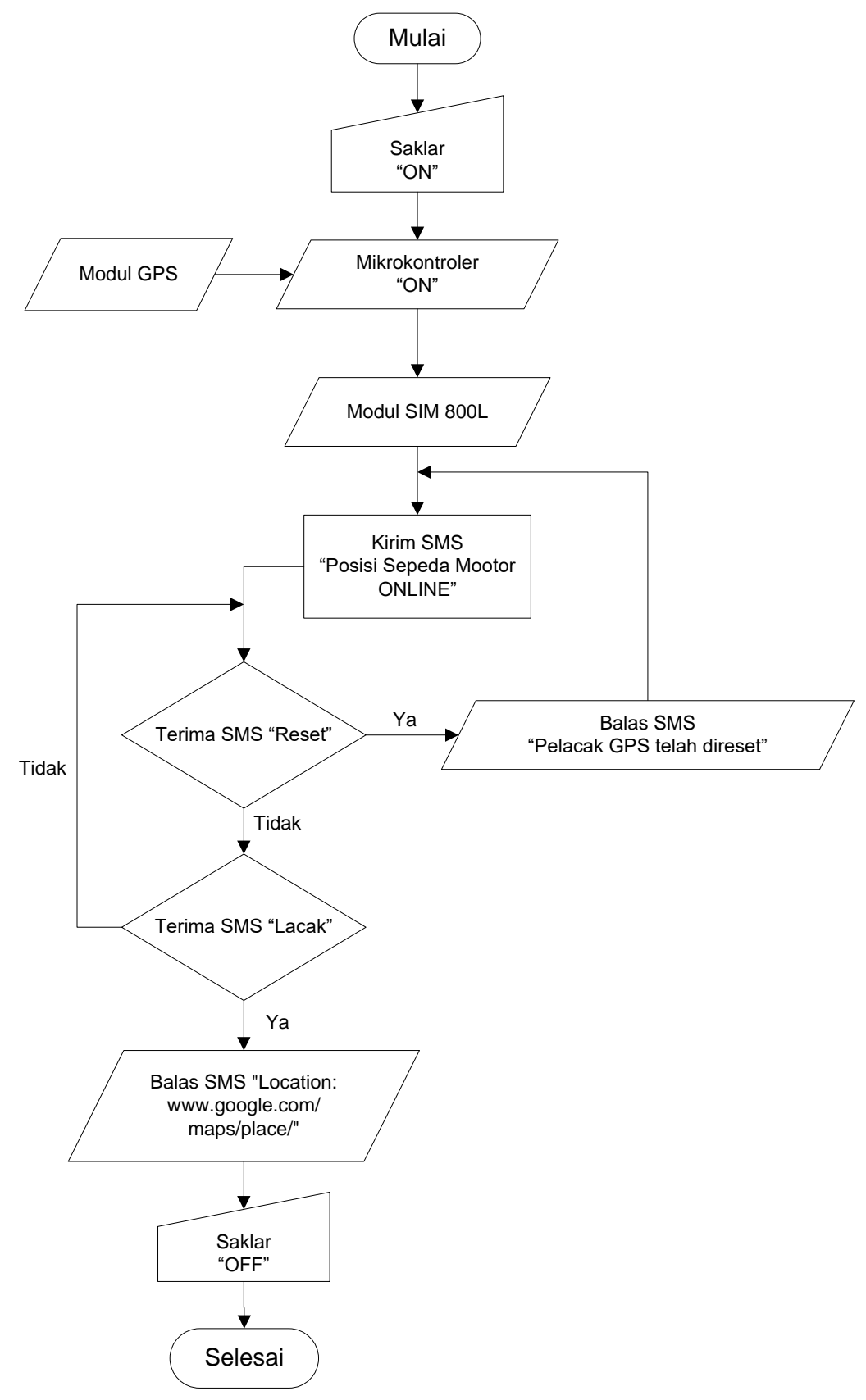

\section{Gambar 4. Diagram Alir Prinsip Kerja Perangkat GPS}

Dengan menekan saklar pada perangkat helm pada posisi "1" maka akan mengaktifkan Arduino nano, DFPlayer beserta speaker, buzzer dan modul nRF24L01. Dengan menyambungkan tali pemegang helm yang berarti menekan limit switch pada posisi "1" maka akan mengaktifkan relay pada perangkat sepeda motor pada posisi "1", dalam keadaan ini sepeda motor sudah siap dioperasikan dengan menekan tombol "starter". 


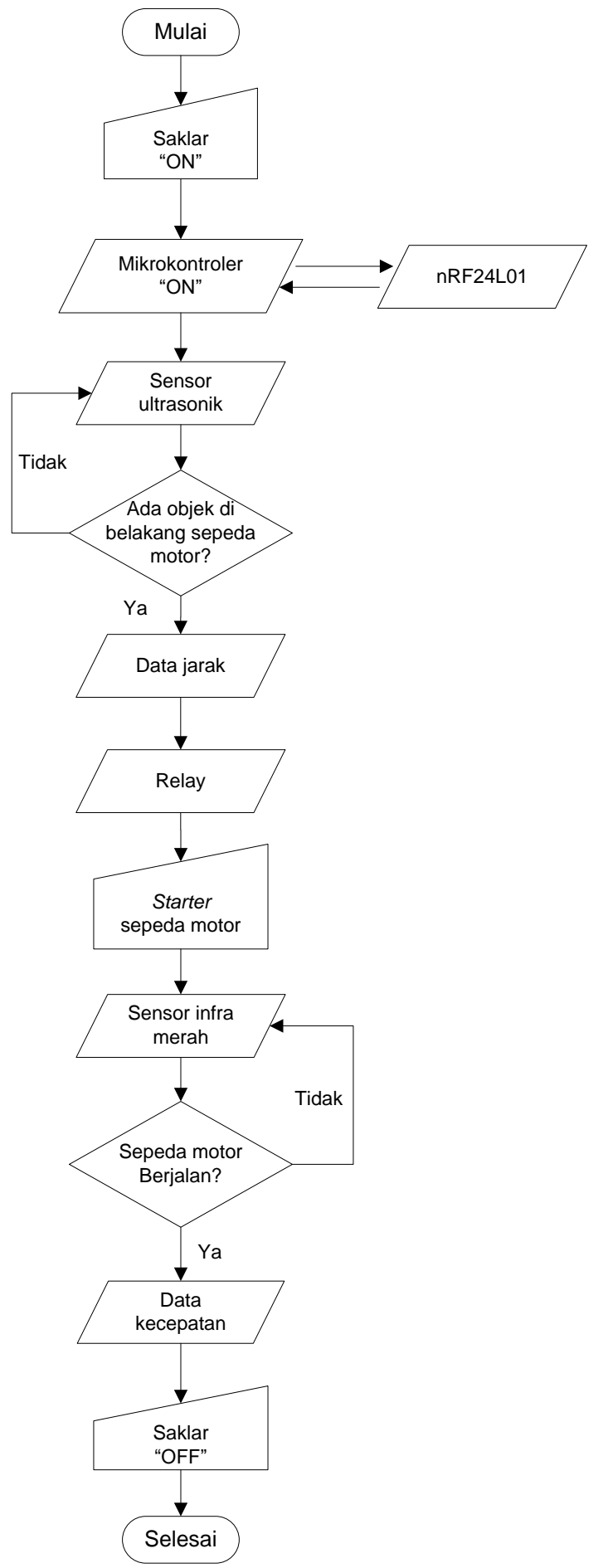

\section{Gambar 5. Diagram alir prinsip kerja perangkat GPS}

Dalam keadaan kedua perangkat ini telah menyala maka sensor ultarsonik akan terus mengukur jarak objek dibelakang sepeda motor dalam jangkauan 4 meter [10]. Buzzer pada perangka helm akan berbunyi dengan frekuensi semakin tinggi jika objek semakin dekat. Demikian juga dengan sensor inframerah akan terus mengukur jumlah putaran roda sepeda motor setelah dikonversikan kedalam satuan kecepatan yaitu kilometer per jam (kmph) [11]. Dengan bantuan pemutar file suara modul DFPlayer mini [12], Speaker pada perangkat helm akan memberitahukan kecepatan yang sedang berlangsung sesuai dengan yang tersimpan pada kode program seperti yang ditunjukkan oleh Gambar 6 [13]. 


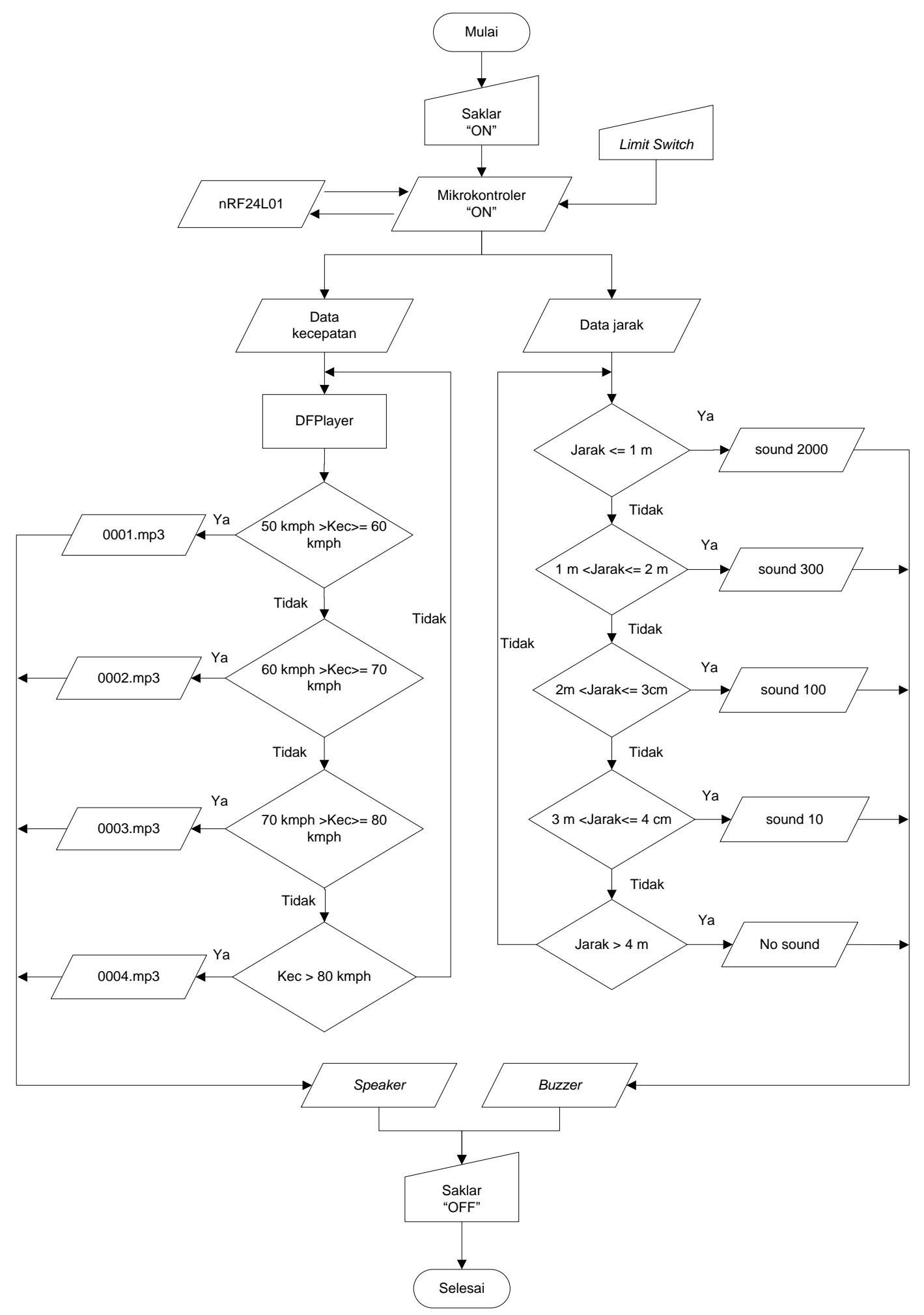

Gambar 6. Diagram alir prinsip kerja perangkat helm

Saat sepeda motor berhenti kemudian tali pengikat helm dilepas yang berarti limit switch pada posisi " 0 " maka perangkat pada helm akan mengirimkan data kepada perangkat sepeda motor untuk memberi perintah kepada relay agar dalam kondisi semula atau Normally Open (NO) kemudian mesin sepeda motor berhenti. 


\subsection{Pengujian Sistem}

Pengujian sistem meliputi menghitung lamanya waktu mulai dari input diberikan sampai reaksi output terdengar atau terlihat. Gambar 7(a) merupakan pengujian dari waktu tanggapan dari limit switch sebagai input dan relay sebagai output terhadap jarak antara keduanya. Gambar 7(b) merupakan pengujian waktu tanggapan mulai dari sensor ultrasonik mengukur jarak tertentu sebuah objek sampai suara buzzer dalam perangkat helm terdengar. Sedangkan gambar 7(c) merupakan pengujian waktu tanggapan mulai dari sensor infra merah mengukur kecepatan sudut tertentu dari simulator roda sampai speaker memberitahukan nilai kecepatan tersebut.

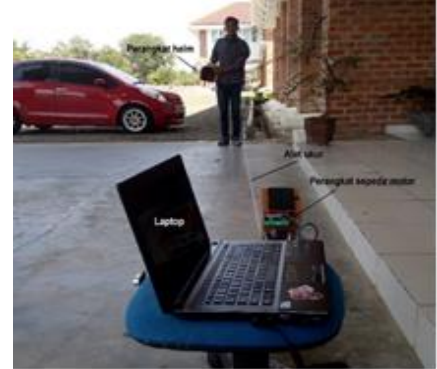

(a)

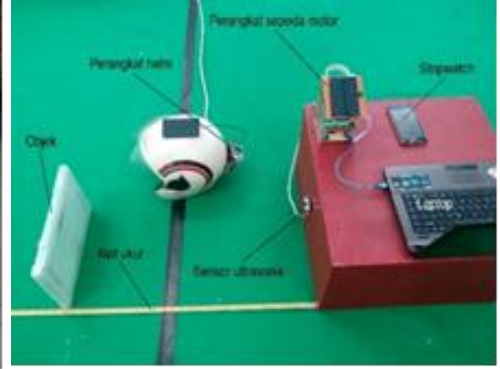

(b)

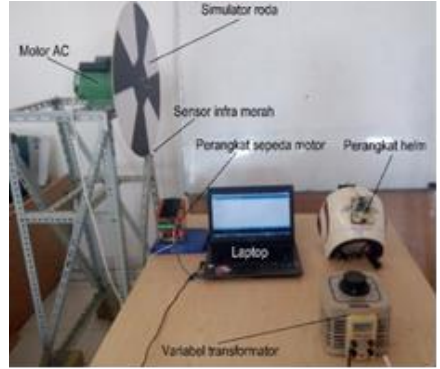

(c)

Gambar 7. Pengambilan Data Waktu Tanggapan Antara (A) Limit Switch dan Modul Relay (B) Sensor Ultrasonik Dan Buzzer, (C) Sensor Infra Merah dan Speaker

Untuk pengujian perangkat pelacak GPS dilakukan dengan meletakkan perangkat dalam radius mulai dari 0 kilometer, 1 kilometer sampai 5 kilometer terhadap smartphone, masing-masing pada ruang terbuka dan ruang tertutup. Parameter yang diambil datanya adalah berapa lama waktu yang dibutuhkan perangkat pelacak GPS untuk membalas sebuah pesan singkat dari smartphone dan seberapa akurat pembacaan dari modul GPS membaca posisi koordinatnya sendiri.

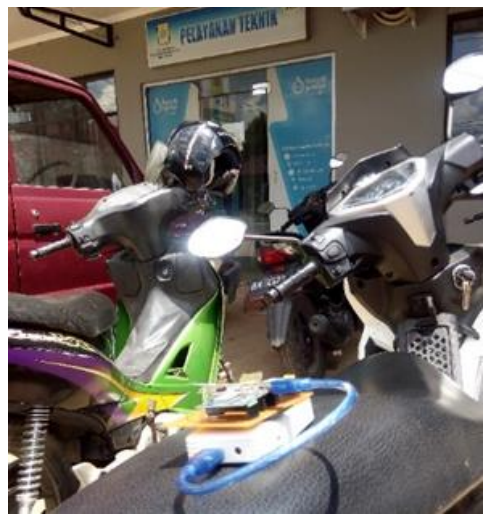

(a)

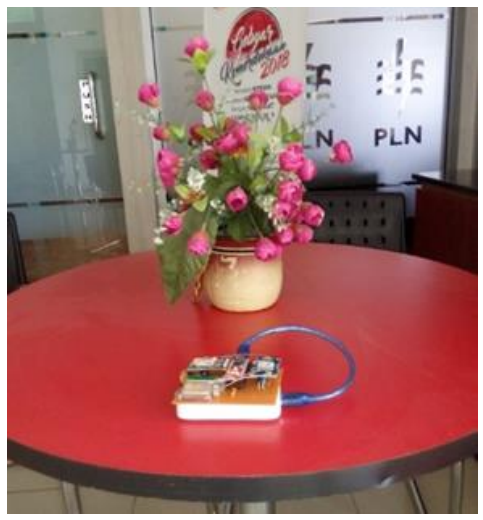

(b)

Gambar 8. Salah Dua Pengambilan Data Perangkat Pelacak GPS (A) Ruang Terbuka (B) Ruang Tertutup

\subsection{Aplikasi Pada Sepeda Motor}

Telebih dahulu pada velg roda depan sepeda motor sisi sebelah kiri diberi warna putih pada empat bagian yang sama hingga mengelilingi velg. Perangkat sepeda motor diikatkan pada sisi kiri dari garpu sepeda motor. Sensor infra merah diarahkan tegak lurus terhadap velg sepeda motor yang telah diberi warna putih dengan jarak 1,5 cm sampai $2 \mathrm{~cm}$. Sensor ultrasonik direkatkan pada bagian belakang motor di atas plat nomor kendaraan dan di bawah lampu rem seperti ditunjukkan pada Gambar 9. 


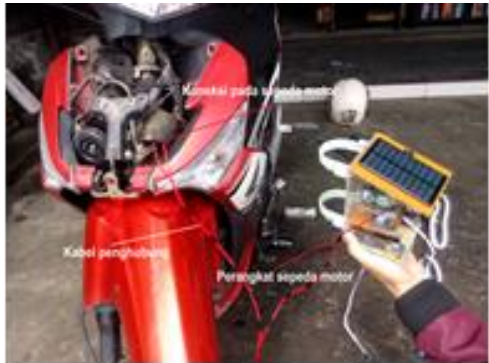

(a)

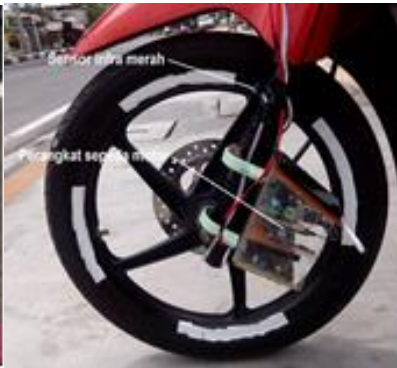

(b)

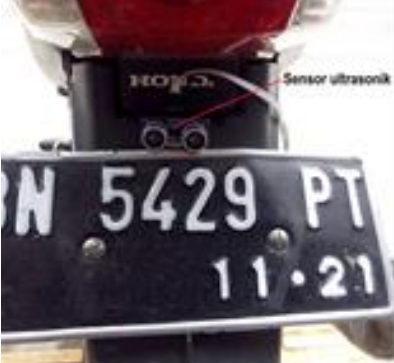

(c)

\section{Gambar 9. Aplikasi Sistem (A) Jalur Pengganti Kunci Kontak (B) Letak Perangkat Sepeda Motor (C) Letak Sensor Ultrasonik}

Untuk menghubungkan perangkat sepeda motor secara elektris ke sepeda motor, hubungkan koneksi $\mathrm{C}$ pada relay ke ujung kutub positif dari aki dan hubungkan koneksi NO pada relay ke ujung selenoid dari relay starter, seperti ditunjukkan pada Gambar 10.

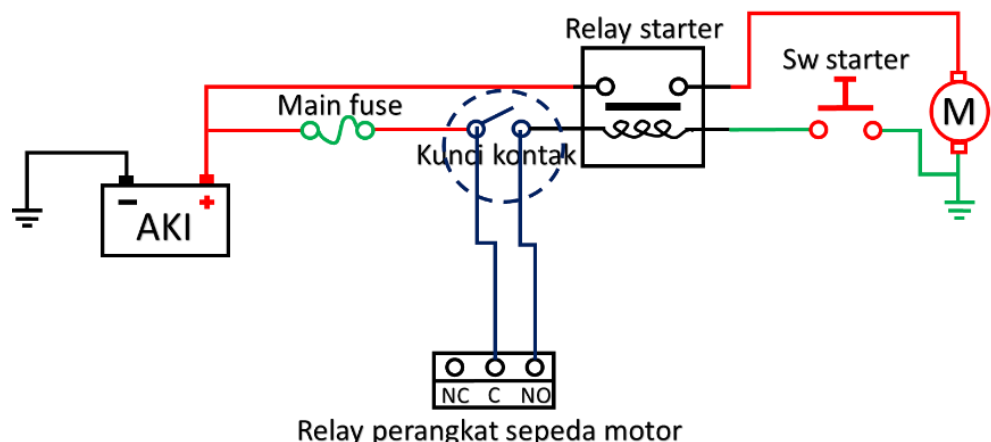

Gambar 10. Rancangan Modifikasi Rangkaian Listrik Sepeda Motor

\section{HASIL DAN PEMBAHASAN}

Dalam penelitian ini pengujian dilakukan untuk mengetahui berapa lama output bereaksi mulai dari input diberikan terhadap variabel, dalam penelitian ini variabelnya adalah jarak dan kecepatan. Sedangkan untuk perangkat pelacak GPS untuk mengetahui berapa lama waktu respon perangkat membalas setelah sebuah pesan singkat diterima dan seberapa akurat koordinat yang dikirimkan ke telepon pintar.

\subsection{Data Hasil Waktu Tanggapan Antara Limit Switch dan Modul Relay}

Pada Gambar 11. menunjukkan sebuah grafik hubungan antara waktu tanggapan yang diberikan oleh relay yang berada pada perangkat helm terhadap jarak perangkat helm dan perangkat sepeda motor. Waktu tanggapan merupakan rentang waktu mulai dari limit switch yang terpasang pada tali pemegang helm dalam kondisi "ON" sampai relay pada kondisi "ON" juga. Variabel jarak merupakan letak antara kedua perangkat yang divariasikan tiap 2 meter hingga mencapai jankauan 100 meter.

Dari data yang diperoleh sebanyak 40 data ada kecenderungan tren naik pada grafik sehingga untuk sementara dapat disimpulkan bahwa jarak antara perangkat helm dan perangkat sepeda motor dapat mempengaruhi waktu tanggapan relay. Jangkauan maksimal untuk pengujian ini adalah 80 meter. 


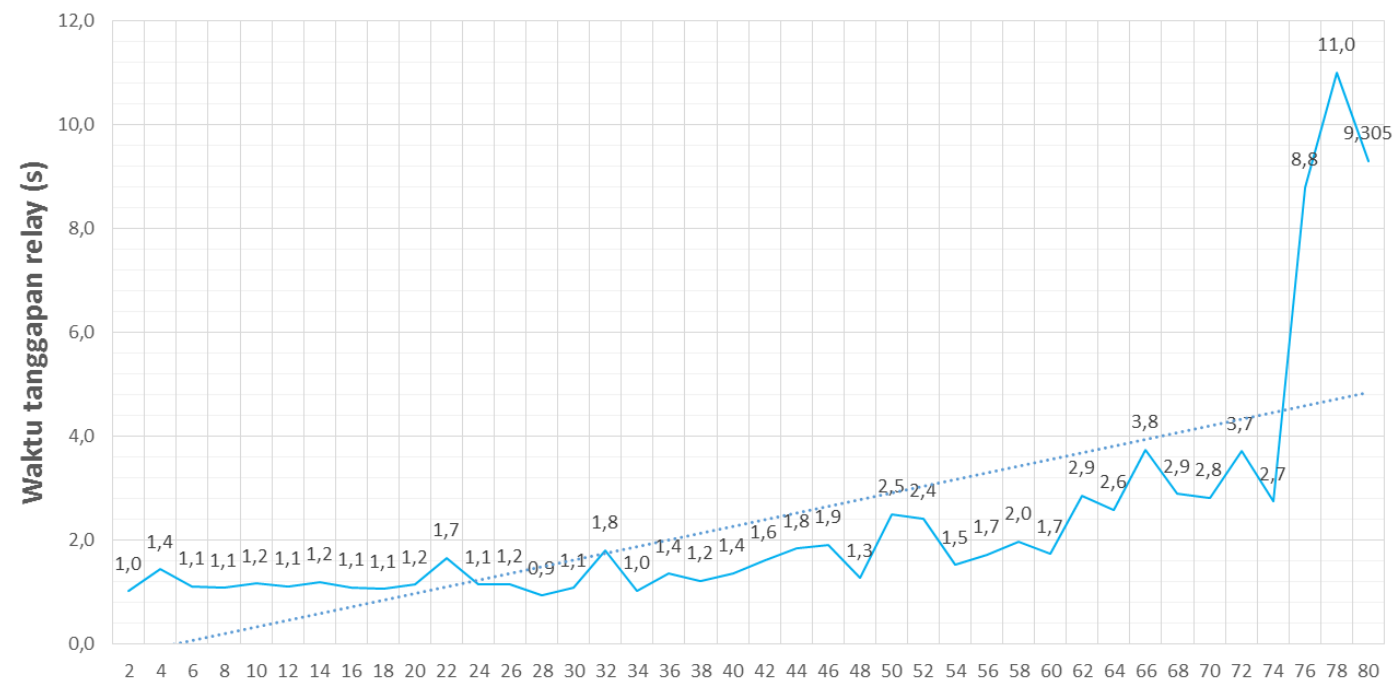

Jarak perangkat helm dan perangkat sepeda motor $(\mathrm{m})$

\section{Gambar 10. Grafik Waktu Tanggapan Relay}

\subsection{Data Hasil Waktu Tanggapan Antara Sensor Ultrasonik Dan Buzzer}

Gambar 12 merupakan sebuah grafik hubungan antara waktu tanggapan yang diberikan buzzer yang berada pada perangkat helm terhadap jarak antara sensor ultrasonik dan objek. Waktu tanggapan merupakan rentang waktu mulai dari sebuah objek diletakkan di depan sensor ultrasonik sampai buzzer mengeluarkan suara. Variabel jarak adalah letak objek terhadap sensor ultrasonik.

Data yang diperoleh pada grafik menunjukkan bahwa jarak objek dan sensor ultrasonik tidak begitu berpengaruh terhadap waktu tanggapan, tapi secara keseluruhan grafik memperlihatkan tren menurun. Jarak objek dan sensor divariasikan tiap 10 sentimeter hingga mencapai 400 sentimeter.

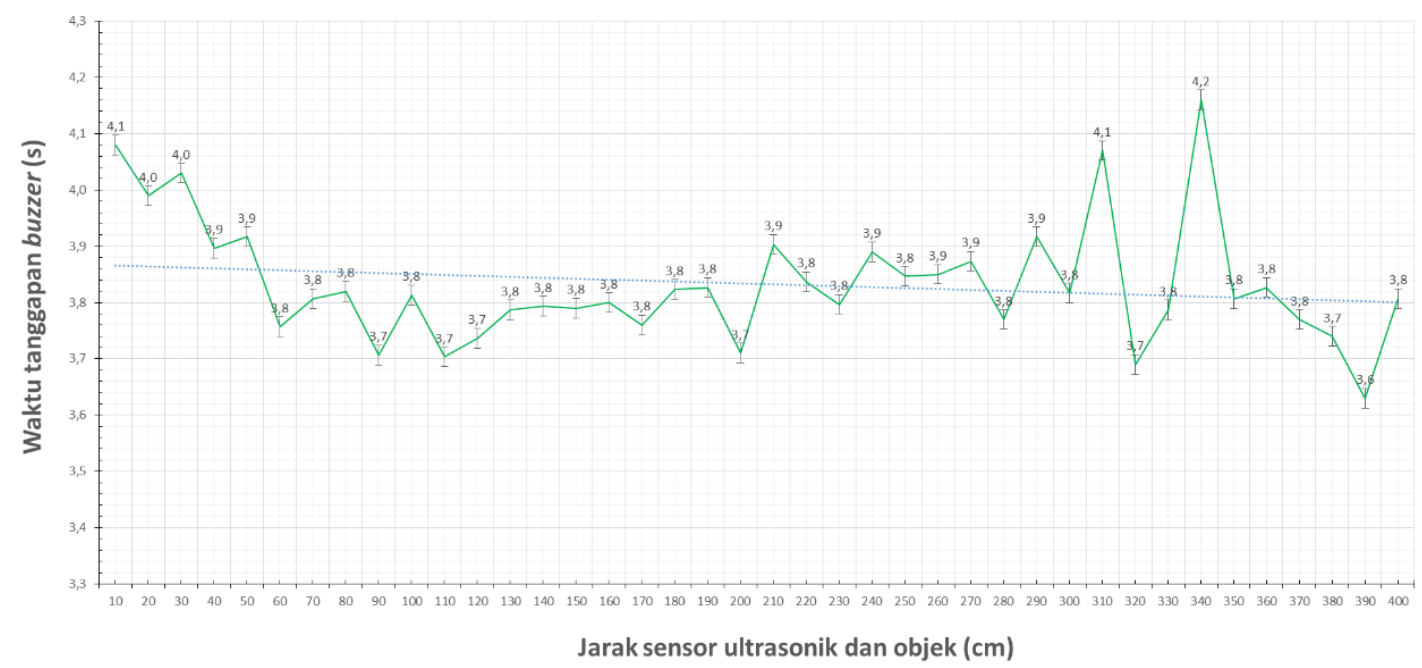

\section{Gambar 12. Grafik Waktu Tanggapan Buzzer}

\subsection{Data Hasil Waktu Tanggapan Antara Sensor Infara Merah Dan Speaker}

Gambar 13 merupakan grafik hubungan antara waktu tanggapan speaker terhadap kecepatan laju roda. Waktu tanggapan merupakan rentang waktu mulai dari saat kecepatan tertentu laju roda sampai speaker mengeluarkan suara peringatan. Variabel kecepatan adalah laju dari simulator roda yang dikondisikan hingga mencapai nilai tertentu.

Data yang ditunjukan oleh grafik menjelaskan bahwa kecepatan laju roda tidak mempengaruhi dari waktu tanggapan speaker untuk memberikan suara peringatan karena tren dari grafik tidak menunjukkan perubahan yang cukup besar. 


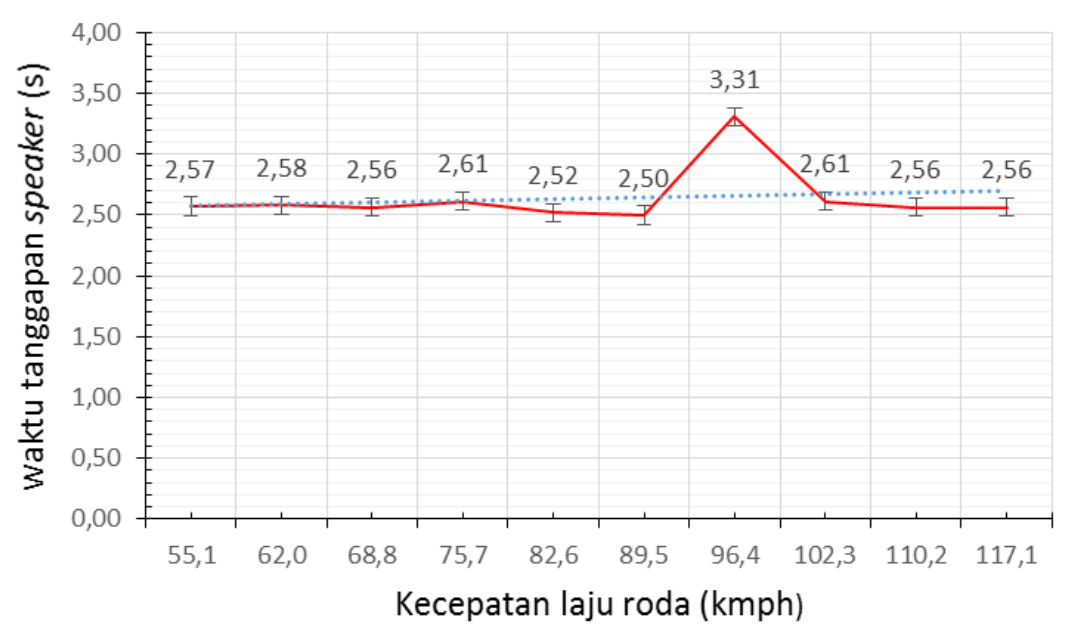

Gambar 13. Grafik Waktu Tanggapan Speaker

\subsection{Data Hasil Waktu Tanggapan Antara Smartphone Dan Perangkat Pelacak GPS}

Tabel 1 merupakan hasil dari pengujian respon sms dan akurasi posisi dari perangkat pelacak GPS pada ruang tertutup dan terbuka. Data dalam kolom respon SMS diperoleh dari penghitungan rentang waktu mulai dari sebuah pesan singkat terkirim ke nomor tujuan yang berada pada perangkat pelacak GPS sampai perangkat membalas dengan pesan link google maps.

Data kolom akurasi posisi diperoleh dengan mengukur posisi koordinat koordinat yang diterima dari perangkat pelacak GPS dengan posisi perangkat sebenarnya dengan menggunakan aplikasi google maps seperti ditunjukkan oleh gambar 14.

Hipotesa yang bisa diambil dari data yang tersaji bahwa radius antara telpon pintar dan perangkat tidak memperngaruhi cepatnya perangkat pelacak GPS membalas pesan singkat dan juga akurasi posisi dari perangkat pelacak GPS.

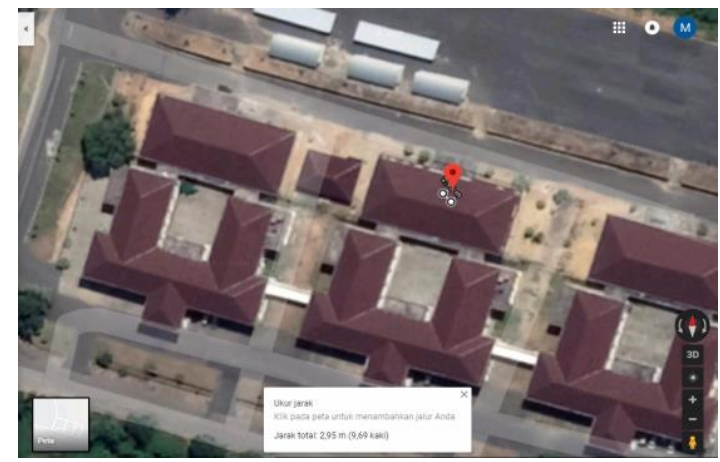

(a)

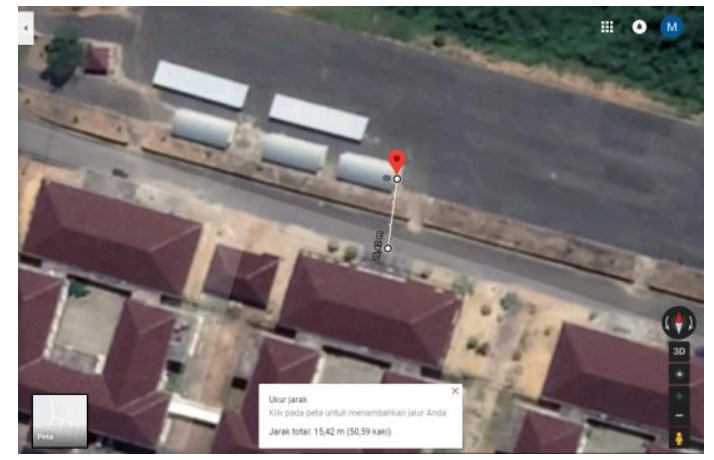

(b)

Gambar 14. Pengukuran Akurasi Menggunakan Aplikasi Google Maps (A) Ruang Tertutup (B) Ruang Terbuka 
Tabel 1. Waktu respon SMS dan akurasi posisi perangkat pelacak GPS

\begin{tabular}{ccccc}
\hline $\begin{array}{c}\text { Radius antara } \\
\text { telepon dan } \\
\text { perangkat }\end{array}$ & \multicolumn{3}{c}{$\begin{array}{c}\text { Respon SMS } \\
\text { (detik) }\end{array}$} & \multicolumn{2}{c}{$\begin{array}{c}\text { Akurasi posisi } \\
(\boldsymbol{m})\end{array}$} \\
$\begin{array}{c}\text { pelacak GPS } \\
(\boldsymbol{k m})\end{array}$ & $\begin{array}{c}\text { Ruang } \\
\text { tertutup }\end{array}$ & $\begin{array}{c}\text { Ruang } \\
\text { terbuka }\end{array}$ & $\begin{array}{c}\text { Ruang } \\
\text { tertutup }\end{array}$ & $\begin{array}{c}\text { Ruang } \\
\text { terbuka }\end{array}$ \\
\hline 0 & 15,60 & 26,80 & 10.08 & 3,80 \\
1 & 15,30 & 12,07 & 1,55 & 2,51 \\
2 & 11,88 & 35,28 & 2,03 & 5,01 \\
3 & 16,56 & 13,30 & 4,98 & 11,10 \\
4 & 11,08 & 11,36 & 4,09 & 5,05 \\
5 & 14,16 & 35,38 & 20,88 & 1,09 \\
\hline
\end{tabular}

\section{KESIMPULAN}

Berdasarkan hasil dari tahapan-tahapan penelitian yang telah dilakukan maka dapat disimpulkan sebagai berikut :

a) Helm dan sepeda motor dapat diintegrasikan secara nirkabel dengan menggunakan modul nRF24L01, sehingga fungsi helm sebagai kunci kontak dan pemberi peringatan telah berhasil diuji-cobakan.

b) Pesan singkat pembacaan koordinat dari perangkat pelacak GPS dapat diterima dan dibaca oleh telpon pintar.

\section{UCAPAN TERIMA KASIH}

Terima kasih kami ucapkan Laboratorium Jurusan Teknik Elektro Universitas Bangka Belitung (JTEUBB) yang telah memfasilitasi selama penelitian ini dan terkhusus Mas Eri Haryono, S.P. yang telah meminjamkan sepeda motor dan menjadi kreator proses dokumentasi.

\section{DAFTAR PUSTAKA}

[1] M. P. R. Indonesia, "Tata Cara Penetapan Batas Kecepatan," Peratur. Menteri Perhub. Repub. Indones. Nomor PM, vol. 111, 2015.

[2] D. V. Zainuddin, N. Yuniar, dan A. F. Fachlevy, "Faktor yang Berhubungan dengan Keparahan Korban Kecelakaan Lalu Lintas pada Pengendara Sepeda Motor di Igd Rumah Sakit Umum Daerah Kota Kendari Tahun 2016," J. Ilm. Mhs. Kesehat. Masy., vol. 1, no. 3, 2017.

[3] S. Kriminal, "Katalog BPS: 4401001 (2014)," Jkt. BPS.

[4] B. D. Magrhobi, "Tinjauan Kriminologis Faktor Penyebab Terjadinya Tindak Pidana Pencurian Kendaraan Bermotor (Studi di Lembaga Pemasyarakatan Lowokwaru Malang),” Kumpul. J. Mhs. Fak. Huk., vol. 1, no. 1, 2014.

[5] B. I. Sumarno dan Y. Brianorma, "Sistem Peringatan Dini Bencana Banjir Berbasis Mikrokontroler Atmega 16 Dengan Buzzer Dan Short Message Service (SMS)," J. Coding Sist. Komput. Univ. Tanjungpura, vol. 1, no. 1, 2010.

[6] D. I. Af'idah, A. F. Rochim, dan E. D. Widianto, "Perancangan Jaringan Sensor Nirkabel (JSN) untuk Memantau Suhu dan Kelembaban Menggunakan nRF24L01+," J. Teknol. Dan Sist. Komput., vol. 2, no. 4, hlm. 267-276, 2014.

[7] V. K. Jain dan A. Parakh, “AutomobileSecurity System using GPS and GSM,” J. Instrum. Innov. Sci., vol. 1, no. 1, 2, 3, 2016.

[8] D. Nataliana, "Perancangan Dan Realisasi Sistem Transmisi Data GPS Menggunakan Teknologi SMS (Short Messaging Service) Sebagai Aplikasi Sistem Personal Tracking," ELKOMIKA J. Tek. Energi Elektr. Tek. Telekomun. Tek. Elektron., vol. 1, no. 1, hlm. 48, 2013.

[9] O. B. Olalekan, "Development of a Sim8001 Based Reprogrammable Household Smart Security System with Recipient Phone Call Alert,” Int. J., vol. 4, no. 1, hlm. 15-20, 2017.

[10] A. Carullo dan M. Parvis, "An ultrasonic sensor for distance measurement in automotive applications," IEEE Sens. J., vol. 1, no. 2, hlm. 143, 2001.

[11] M. M. Rana, M. Sahabuddin, dan S. Mondol, "Design and Implementation of a Digital Tachometer," memory, vol. 2, hlm. 3, 2016.

[12] L. Maulana dan D. Yendri, "Rancang Bangun Alat Ukur Tinggi dan Berat Badan Ideal Berdasarkan Metode Brocha Berbasis Mikrokontroler," J. Inf. Technol. Comput. Eng., vol. 2, no. 02, hlm. 26-34, 2018. 
Jurnal SIMETRIS, Vol. 10 No. 1 April 2019

P-ISSN: 2252-4983, E-ISSN: 2549-3108

[13] D. Wijayanto, S. Hadiyoso, dan Y. S. Hariyani, "Implementasi Sistem Pemanggil Antrian Dengan Tampilan Seven Segment Berbasis Mikrokontroler Pada Pt Pln Sukoharjo," EProceedings Appl. Sci., vol. 1, no. 1, 2015. 